\title{
Analysis of the influence of column reinforcement anchorage length in a concrete two-pile cap
}

\section{Análise da influência do comprimento de ancoragem da armadura do pilar no bloco sobre duas estacas}
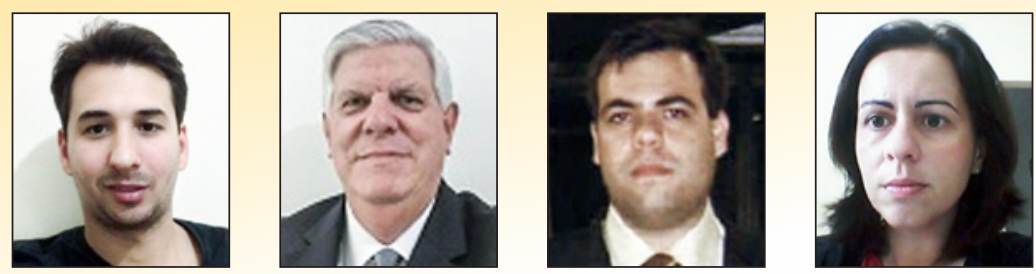

R. P. RANDI ricardo_randi@hotmail.com

L. C. ALMEIDA a almeida@fec.unicamp.br

L. M. TRAUTWEIN a leandromt@fec.unicamp.br

F. S. MUNHOZ b

fabiana.munhoz@fatec.sp.gov.br

\section{Abstract}

This paper describes the parametric analysis applied to assess the influence of column anchorage-reinforcement length on concrete two-pile caps under uniform compression. The non-linear numerical analysis was conducted with the bi-dimensional elements of ATENA 2D software, considering perfect adherence between steel and concrete. Simulation was based on the experimental reference model by Munhoz [1], which was the parameter adopted to validate the numerical modeling. From the validated model, four different anchorage reinforcement lengths were adopted, $34,0 \mathrm{~cm}, 20,0 \mathrm{~cm}, 10,0 \mathrm{~cm}$ e $3,0 \mathrm{~cm}$, in order to compare pile caps behavior after these changes. Pile cap simulations presented similar behavior, i.e., column anchorage reinforcement length is not a preponderant factor for the internal mechanisms that regulate the function of these elements.

Keywords: reinforced concrete, pile caps, anchorage, numerical analysis, finite elements.

\section{Resumo}

Este artigo analisa parametricamente a influência do comprimento da armadura de ancoragem do pilar em um bloco de concreto sobre duas estacas, submetido à compressão uniforme. A análise numérica não linear é realizada com o emprego dos elementos finitos bidimensionais do programa computacional ATENA 2D, considerando aderência perfeita entre aço e concreto. A simulação é baseada em um modelo experimental de referência, oriundo da pesquisa de Munhoz [1], utilizado como parâmetro para validar a modelagem numérica. A partir do modelo validado, adotaram-se quatro comprimentos diferentes de ancoragem das armaduras do pilar, sendo $34,0 \mathrm{~cm}, 20,0 \mathrm{~cm}, 10,0 \mathrm{~cm}$ e $3,0 \mathrm{~cm}$, a fim de comparar o comportamento dos blocos após essas alterações. As simulações dos blocos apresentaram comportamentos semelhantes, ou seja, o comprimento das armaduras de ancoragem dos pilares não é um fator preponderante para os mecanismos de funcionamento interno desses elementos.

Palavras-chave: concreto armado, blocos sobre estacas, anccoragem, análise numérica, elementos finitos. 


\section{Introduction}

The theory by Blévot \& Frémy [2] is the most accepted and widespread one to describe pile cap behavior, since their study became a reference for other researchers and codes. The Strut and Tie Model is their main contribution to this field, because it consistently explains the cap stress flows. According to the aforementioned authors, most tested models failed due to struts concrete crushes after cracks emerged parallel to the compressive stress flows. The tensile stress actions, perpendicular to the struts caused these cracks. Such process is also known as splitting effect.

Studies performed in the following decades corroborated assertively these conclusions. With the computer software evolution and the Finite Elements Method allowed a refined analysis about the behavior of pile caps.

Mautoni [3] deepened the studies about pile cap failure mechanisms. Tests were performed with models in different reinforcement distributions and also found that they failed due to struts concrete crushes (splitting effect), corroborating with Blévot \& Frémy [2] results.

Buttignol [4] performed numerical analysis based on Delalibera [5] and Miguel's [6] experimental tests and also observed, as aforementioned authors, the splitting effect and compressive struts formation. Also according to Buttignol [4], the numerical and experimental comparative results demonstrated the complexity of laboratorial tests reproduced in computers. Pile cap structural stiffness was one of the main differences found, and this finding was also observed by Delalibera [5], who recorded three factors to explain the greater stiffness observed in numerical models: experimental model accommodation at test start, perfect adhesion between reinforcement bars and concrete, and the assumption of perfect connection between piles and cap.

Related to this paper, compares will be performed between experimental and numerical pile caps with two piles, in order to validate the numerical simulation conducted in ATENA 2D software, in which experimental results come from results by Munhoz1s [1] research.
Specifically, the behavior of columns anchorage reinforcement will be analyzed. Papers about this subject remain scarce in the literature. Notably Munhoz [1] analyzed, among other results, the influence of column sections and of different reinforcement rates on stress transmission between columns and pile caps. According to author's analysis, column anchorage reinforcement strains and stress tend to decrease throughout the column's length; however, they are transferred to the pile cap, after a certain depth, depending on the columns' transversal section and on reinforcement rate and distribution.

\subsection{Justification}

Pile caps are important structural elements of stress transition between superstructures and infrastructures. Main codes such as ACI 318 [7], CEB-FIP [8] and ABNT NBR6118/2014 [9] indicate the struts and the tie model applied to pile caps design. Therefore, further studies are essential to help better understanding the behavior, since it would make pile caps designs more safe.

Besides experimental tests, the advancement of computer software and the Finite Elements Method allowed many researchers to use numerical simulations in their studies. However, numerical analysis results must represent accurate structure behavior simulations. Therefore, experimental and numerical comparisons must be studied in order to understanding the convergence and divergence between models, aiming a better use of software.

Related to this paper core, i.e., the behavior of column anchorage reinforcement in pile caps with two piles, this work is justified by the scarcity of researches in this subject. It is expected to improve the codes and to provide more accurate and economic models based on reliable reinforcement anchorage results.

\section{Analysis methodology}

Comparisons were performed on the behavior of pile caps with two piles. Numerical pile caps were modelled in the ATENA 2D

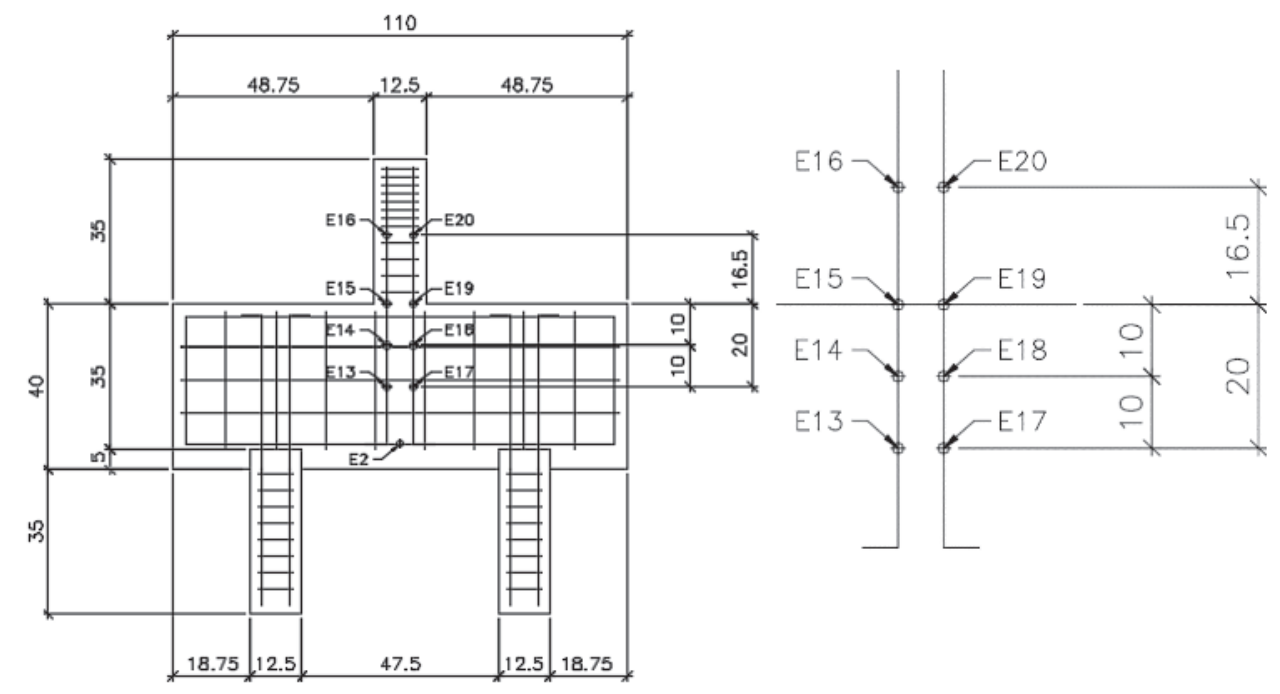

Figure 1

Geometry, reinforcement dispose and strain gage location in analyzed model 


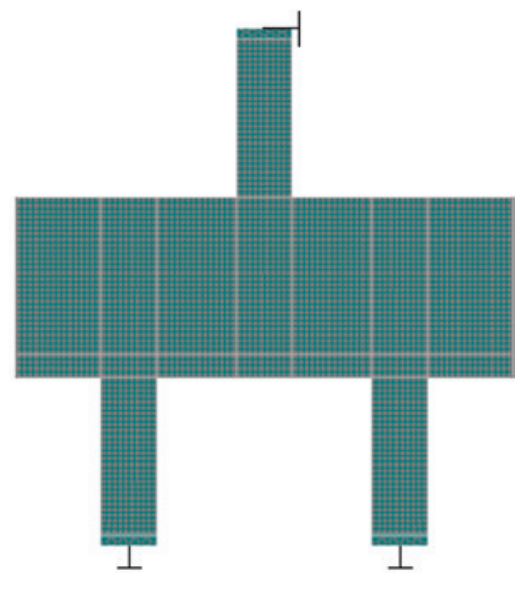

Figure 2

Finite elements discretization of numerical model B1 10P125R2.5M1

software. Steel/concrete material properties and element geometry were assessed based on experimental tests and on the B110P125R2.5 model by Munhoz [1].

Pile cap model geometry is $110.0 \mathrm{~cm} \times 15.0 \mathrm{~cm} \times 40.0 \mathrm{~cm}$, presented in Figure 1. Tie reinforcement is composed of four bars (12.5 $\mathrm{mm}$ ) above the piles, superior reinforcement comprised three bars $(10.0 \mathrm{~mm})$ and pile caps reinforcement was completed with horizontal and vertical stirrups bars $(6.3 \mathrm{~mm})$. Piles presented $12.5 \mathrm{~cm}$ $x 12.5 \mathrm{~cm}$ section, $40.0 \mathrm{~cm}$ height $(5.0 \mathrm{~cm}$ inward the pile cap), $10.0 \mathrm{~mm}$ longitudinal reinforcement (inward the pile cap) and 5.0 $\mathrm{mm}$ stirrups along the pile. The column presented a $12.5 \mathrm{~cm} \times 12.5$ $\mathrm{cm}$ section and $35.0 \mathrm{~cm}$ height. Column longitudinal reinforcement is composed of four bars $(12.5 \mathrm{~mm})$ and of bursting reinforcement and stirrups $(5.0 \mathrm{~mm})$ along the column.

Figure 1 shows the location of strain gages adopted to measure the reinforcement strains, which are highlighted by letter E. Five comparative parameters validated the model: load versus displacement curve, failure load, reinforcement strain and stress, stress flows, crack patterns and failure modes.

\section{Numerical analysis}

The nonlinear analysis was performed in the ATENA 2D software, version 5.3.2 (Cervenka Consulting Company), based on the Finite
Elements Method. The theoretical basis of the software is described in the Theoretical Manual - Part 1 (Cervenka Consulting) [10].

The load was applied through load-steps divided into ten $20.0 \mathrm{kN}$ increments, fifteen $10.0 \mathrm{kN}$ increments and $5.0 \mathrm{kN}$ increments until model failure. They were vertically applied to linear loads along the top of the columns. Boundary conditions were imposed at three distinct points: the first two ones to pile axes, restricting vertical model displacements (y direction); and the third ones to the top of the column axis, restricting horizontal model displacements (x direction), as presented in Figure 2. Monitoring points at the reinforcement were placed at strategic positions, based on the model by Munhoz [1], as presented in Figure 1, in order to compare the experimental and numerical models. The Newton-Rhapson Method was adopted for the iterative mathematical calculations to find the convergence between differential functions at each load increment. Increments were performed through load-steps; calculations were made until reaching structure equilibrium and its respective displacements in each iteration. Iterations are repeated until the convergence is found.

For the parametric study applied to assess column reinforcement anchorage length variations in the pile caps, only these lengths were changed in the numerical models, all other characteristics and material mechanical properties remained the same. For the B110P125R2.5 experimental model, four numerical models were simulated varying column reinforcement anchorage length, as presented in Figure 3, identified by the addition of codes M1, M2, M3 and M4 at the end of nomenclature. Model M1 regarded the numerical model presenting column anchorage longitudinal reinforcement length in the pile cap equal to $34.0 \mathrm{~cm}$; similar to the experimental model adopted by Munhoz [1]. Variations M2, M3 and M4 represented the numerical models showing column reinforcement anchorage length in the pile cap equal to $20.0 \mathrm{~cm}, 10.0 \mathrm{~cm}$ and $3.0 \mathrm{~cm}$, respectively.

Material properties subjected to numerical analysis were mostly obtained from results provided by the B110P125R2.5 experimental model, based on Munhoz [1]. The behaviors of materials adopted in the ATENA 2D software are described in the Theoretical Manual - Part 1 (Cervenka Consulting) [10]. The constitutive model of plastic fracture, which is represented by a stress versus strain curve, was applied to concrete (Figure 4(a)). Specific Fracture Energy $\left(G_{f}\right)$, which is an important parameter for concrete-element models, is given through Equation 1; wherein, $f_{t}^{\prime}$ 'f is the effective tensile strength of the concrete. Figure 4(b) depicts the parameter adopted to measure the Specific Fracture Energy rate; it is associated with the behavior of concrete elements subjected to

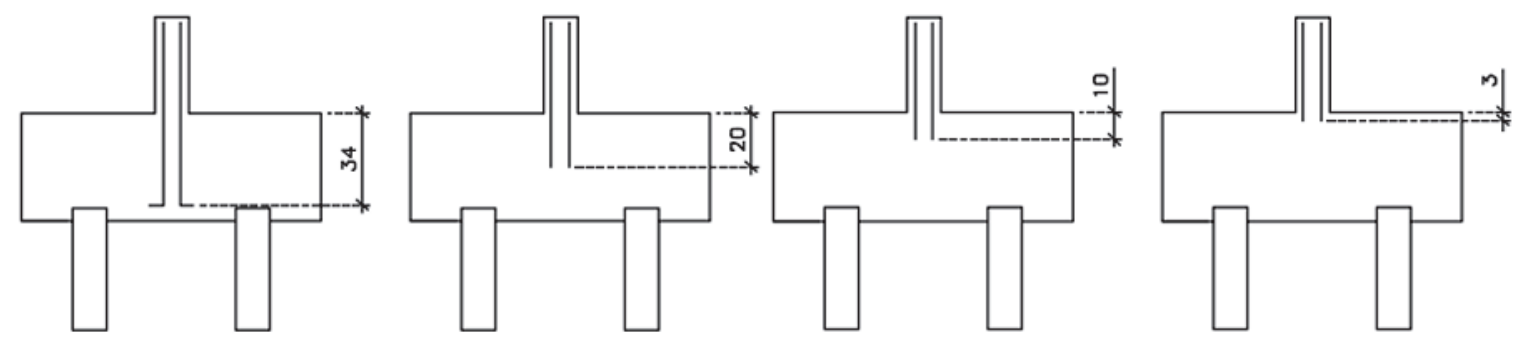

Figure 3

Numerical models group simulated from B1 10P125R2.5 model 


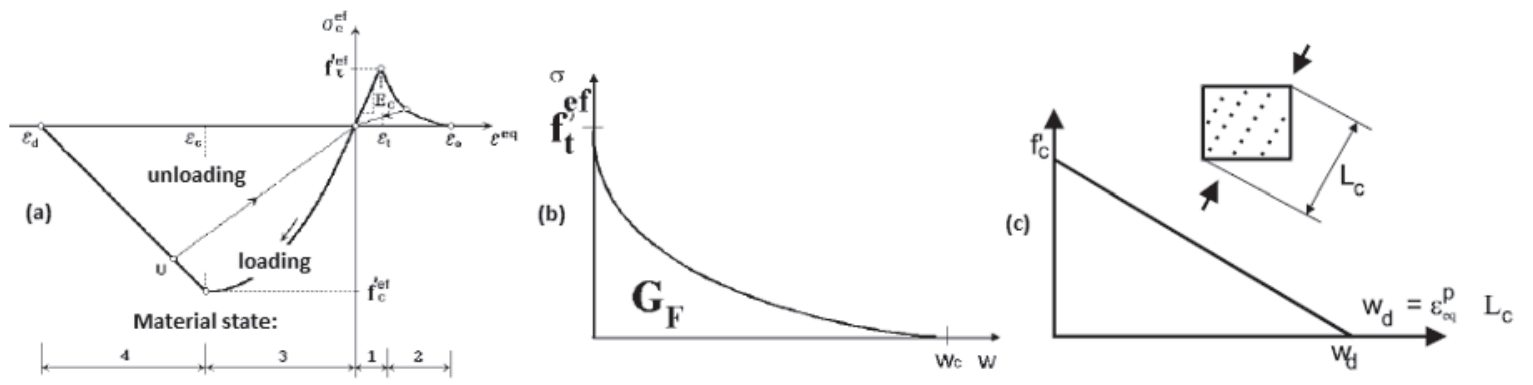

\section{Figure 4}

Stress versus strains curves characteristics of concrete, stress versus crack opening and linear softening by Drucker Prager' Criterion (Cervenka Consulting [10])

nonlinear regime or post-cracking behavior. Hooke's Law describes the tensile behavior of concrete under elastic regime. According to the Theoretical Manual - Part 1 (Cervenka Consulting) [10], the failure-plane behavior after the first cracks openings (post-cracking stress regime) is described through the Drucker-Prager's Plasticity Model (Figure 4(c)). The Rankine's Failure Criterion is adopted to find the compressive behavior.

$G_{f}=0,000025 . f_{t}{ }^{\text {eff }}$

Experimental data obtained by Munhoz [1] was used for the reinforcements stress versus strain curves. ATENA 2D software allows constructing the stress versus strain curve of the known points in order to simulate steel behavior. An isotropic material presenting elastic behavior and plane stress was adopted to steel plates located on pile supports and load application point. Plates were used to help stress distribution in application and reaction load points. A rigid connection was adopted for the plate/column interface and an interface element was adopted for steel/piles interface in order to properly connect plates to concrete elements.

Table 1 and Table 2 present the physical parameters of materials adopted in numerical models. Concrete compressive strength $\left(f_{c}\right)$, tensile strength $\left(f_{t}\right)$, Modulus of Elasticity $\left(E_{c}\right)$ and Poisson's ratio (v) were based on experimental tests; Specific Fracture Energy $\left(G_{f}\right)$ is given through Equation 1. Six parameters were used to simulate the contact and stiffness between adjacent materials in interface elements. Parameters are shown in Table 3.

According to the Theoretical Manual - Part 1 (Cervenka Consulting) [10], interface elements are based on Mohr-Coulomb's Criterion. Normal $\left(\mathrm{K}_{\mathrm{nn}}\right)$ and transversal $\left(\mathrm{K}_{\mathrm{tt}}\right)$ stiffness correspond to the behavior of elastic materials - the maximum values must be ten times higher than the stiffness value recorded for adjacent finite

\section{Table 1}

Concrete material parameters

\begin{tabular}{|c|c|c|c|}
\cline { 2 - 4 } \multicolumn{1}{c|}{} & $\begin{array}{c}\text { Pile cap } \\
\text { and column }\end{array}$ & Pile & Unity \\
\hline Compressive strength $\left(f_{c}\right)$ & 33.86 & 77.91 & $\mathrm{MPa}$ \\
\hline Tensile strength $\left(f_{+}\right)$ & 2.97 & 4.49 & $\mathrm{MPa}$ \\
\hline Modulus of elasticity $\left(\mathrm{E}_{c}\right)$ & 35.110 & 44.050 & $\mathrm{MPa}$ \\
\hline Poisson's ratio $(v)$ & 0.20 & 0.20 & - \\
\hline Specific fracture energy $\left(G_{f}\right)$ & 69.99 & 122.00 & $\mathrm{~J} / \mathrm{m}^{2}$ \\
\hline
\end{tabular}

elements. Minimum stiffness is a numerical assumption adopted after element failure to keep equilibrium continuity in the assessed element; it must be 0,001 times higher than the maximum value. The interface tensile strength $\left(f_{t}\right)$ weights the possibility of having interface material failure due to tensile stress. Cohesion (C) avoids horizontal slips between materials; therefore, it is important observing that cohesion values must be greater than zero in the plate/pile interface, even under vertical and equally distributed load on the plate, because horizontal slips can result from element strains and horizontal crack openings. Figure 5 shows the behavior of interface elements.

\section{Analysis of experimental versus numerical results}

\subsection{Load versus displacement curve and failure load}

Load versus displacement curves, Figure 6, consists of an applied

\section{Table 2}

Steel plates parameters

\begin{tabular}{|c|c|c|}
\cline { 2 - 3 } \multicolumn{1}{c|}{} & Steel plate & Unity \\
\hline Thickness & 2.54 & $\mathrm{~cm}$ \\
\hline Poisson's ratio $(v)$ & 0.30 & - \\
\hline Modulus of elasticity $\left(\mathrm{E}_{\mathrm{s}}\right)$ & 210,000 & $\mathrm{MPa}$ \\
\hline
\end{tabular}

\section{Table 3}

Interface elements parameters

\begin{tabular}{|c|c|c|}
\cline { 2 - 3 } \multicolumn{1}{c|}{} & Plate/Pile interface & Unity \\
\hline $\begin{array}{c}\text { Normal stiffness } \\
\left(k_{n n}\right)\end{array}$ & $1.5 \cdot 10^{5}$ & $\mathrm{MN} / \mathrm{m}^{3}$ \\
\hline $\begin{array}{c}\text { Minimum normal } \\
\text { stiffness }\left(\mathrm{k}_{\mathrm{nn}, \mathrm{min}}\right)\end{array}$ & $1.5 \cdot 10^{2}$ & $\mathrm{MN} / \mathrm{m}^{3}$ \\
\hline $\begin{array}{c}\text { Transversal stiffness } \\
\left(\mathrm{k}_{\mathrm{H}}\right)\end{array}$ & $1.5 \cdot 10^{5}$ & $\mathrm{MN} / \mathrm{m}^{3}$ \\
\hline $\begin{array}{c}\text { Minimum } \\
\text { transversal stiffness } \\
\left(\mathrm{k}_{\mathrm{H}, \mathrm{min}}\right)\end{array}$ & $1.5 \cdot 10^{2}$ & $\mathrm{MN} / \mathrm{m}^{3}$ \\
\hline Tensile strength $\left(\mathrm{f}_{\mathrm{t}}\right)$ & 4.49 & $\mathrm{MPa}$ \\
\hline Cohesion $(\mathrm{C})$ & 5.00 & $\mathrm{MPa}$ \\
\hline
\end{tabular}



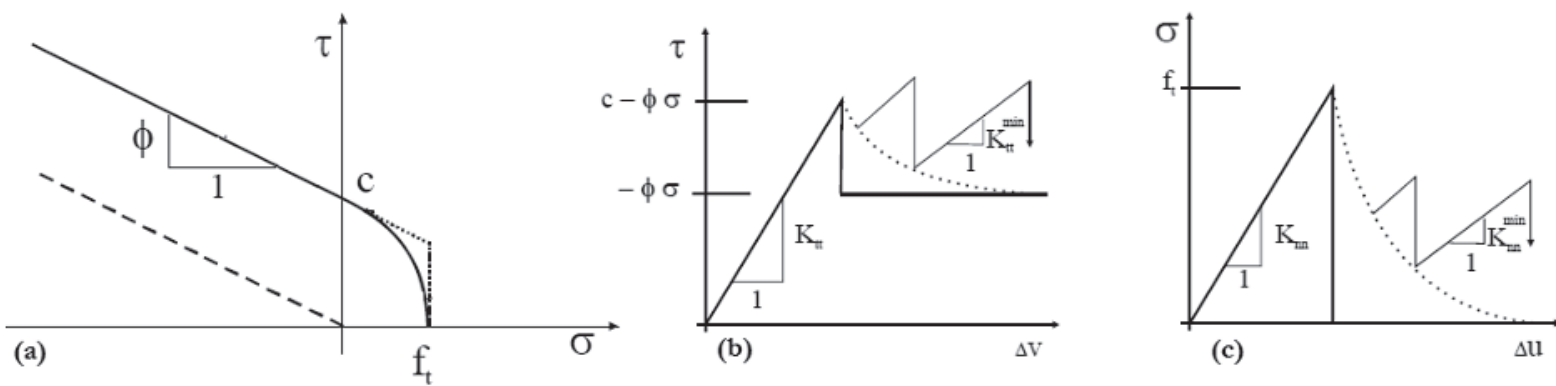

Figure 5

Interface elements behavior (Cervenka Consulting [10])
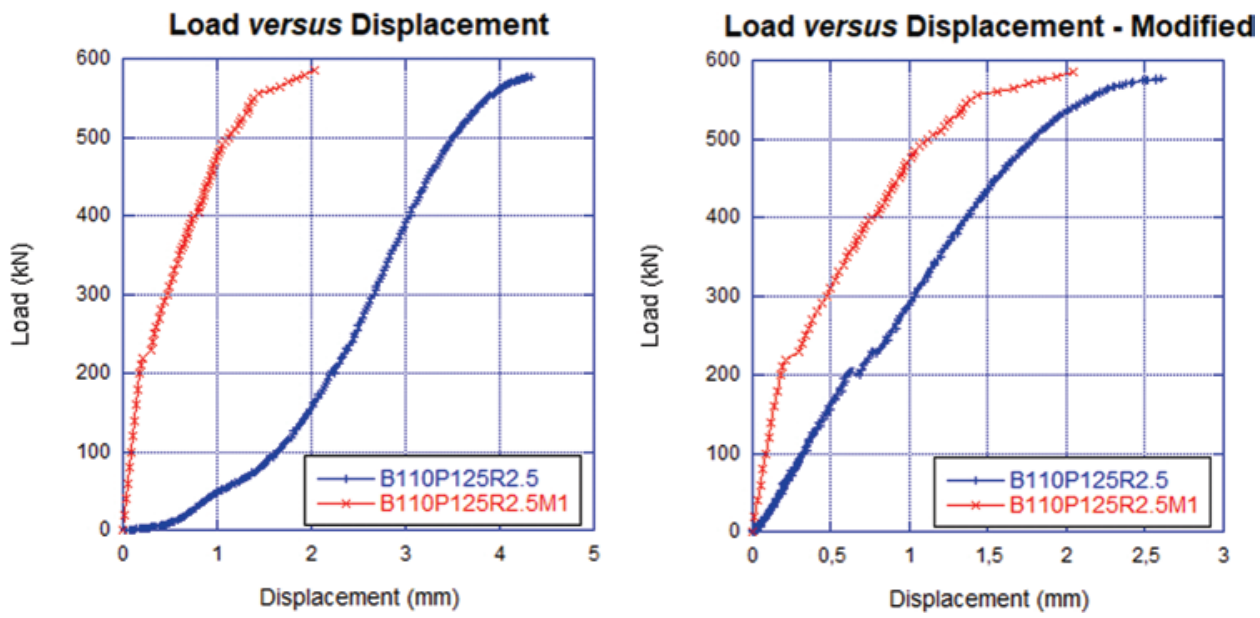

Figure 6

Load versus displacement curve, original and modified, of models B1 10P125R2.5 and B1 10P125R2.5M1

external load and of a vertical displacement measured in the center of the inferior face of the pile cap. These curves show the phenomena of accommodation supports of experimental models at test start, because it is observed a nonlinear interval in the displacement measurements, which broaden the difference between the experimental and numerical curves. Based on Munhoz [1], the left curve shows the original experimental results, and the right one highlights the experimental results modified after nonlinear interval removal.

The experimental and numerical curves became closer to each other and presented similar behavior after the adjustments. Small plateaus can be seen in a certain test point; they were caused by the emergence of the first significant crack opening.

Table 4 presents the failure load values $\left(F_{4}\right)$, the load comparisons $\left(\mathrm{F}_{\text {comp }}\right)$, the maximum failure displacement $\left(\mathrm{W}_{\mathrm{Fu}}\right)$ and the relations between these loads.
The $F_{u, n u m} / F_{u, e x p}$ relation between the failure loads $\left(F_{u}\right)$ of the experimental and the numerical models presented $1.0 \%$ difference; proving that the numerical analysis showed proximity to experimental test. Maximum failure displacement $\left(\mathrm{W}_{\mathrm{Fu}}\right)$ presented some disparities due to stiffness differences between models. This outcome corroborated the results in the research by Buttignol [4] and Delalibera [5].

\subsection{Reinforcement strain-stress}

Four monitoring points were used in column anchorage reinforcement. They were placed in equivalent points of the experimental and numerical models in order to allow verifying strain and stress variations. Based on Figure 1, the E13/E17, E14/E18, E15/E19 and E16/E20 strain gages are symmetric. Only E13, E14, E15 and E16 results will be presented, because symmetry and result proximity were taken into account.

Table 4

Failure loads, comparison loads and maximum failure displacement of B1 1OP125R2.5 and of P125R2.5M1 models

\begin{tabular}{|c|c|c|c|c|c|}
\hline \multirow{2}{*}{ Model } & \multirow{2}{*}{ Type of analysis } & $\mathbf{F}_{\mathrm{u}}$ & $\mathbf{F}_{\text {comp }}$ & $\mathbf{F}_{\mathrm{u}, \text { num }} / \mathbf{F}_{\mathrm{u}, \text { exp }}$ & $-\mathbf{W}_{\mathrm{Fu}}$ \\
\cline { 3 - 6 } & & $\mathbf{( k N )}$ & $\mathbf{( k N )}$ & - & $(\mathbf{m m})$ \\
\hline B110P125R2.5 & Experimental & 577.08 & 491.83 & 1.01 & 2.628 \\
\hline B110P125R2.5M1 & Numerical & 585.00 & 491.83 & 1.01 & 2.044 \\
\hline
\end{tabular}



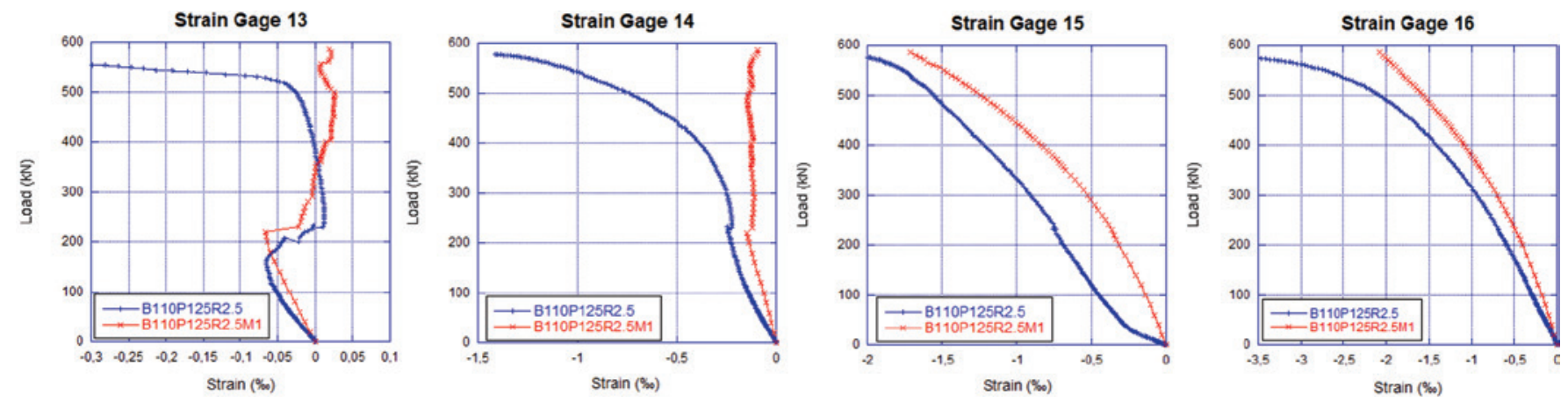

Figure 7

Load versus strain of column anchorage reinforcement, B1 10P125R2.5 e B1 10P125R2.5M1

Figure 7 shows the load versus strain recorded for these strain gages. Two phenomena caused divergences between the experimental and numerical results: experimental models accommodation at test start and the assumption of perfect adhesion between reinforcement and concrete.

Different from the numerical model, in which strain increases smoothly and presents small variations, the strain gage measures of curves E13 and E14 increased abruptly in the experimental model under a given load (approximately $500.0 \mathrm{kN}$ ). Abrupt behaviors are characteristics of slip between reinforcement and concrete which occurs in experimental models; however, this phenomenon is not observed in the numerical models based on perfect adhesion.

There was experimental model accommodation at the beginning of the strain gage E15 curve, and such outcome was previously observed in the load versus displacement curve. The analysis applied to strain gage E16 showed column longitudinal reinforcement yielding in the experimental model. According to data in the study by Munhoz's [1], steel yield strain $\left(\varepsilon_{y, m}\right)$ reaches $3.42 \%$ in $12.5 \mathrm{~mm}$ bars; such maximum strain was reached at approximately $572 \mathrm{kN}$ - lower than the one recorded at test failure load $577.08 \mathrm{kN}$. However, columns in experimental models were wrapped, reinforced with bursting reinforcement besides stirrups; therefore, they were excessively rigid and even their strains were close to the limits, there was no abrupt failure.

Considering above information, some modifications were made in the experimental data to better compare both behavior models, since the numerical models did not show some of the recorded phenomena. Curve results of strain gages 13 and 14, which covered the reinforcement slip phenomena, were removed. The test at start was changed in the strain gage 15 curve to remove the test interval characterized by model accommodation. Strain values above $2.0 \%$ were removed in strain gage 16 , because the maximum strain in concrete was reached. Results of modified curves are shown in Figure 8.

Based on Figure 8, the behavior of experimental and numerical models related to strain gage 13 was similar. Initially, reinforcement was compressed (negative region of the curve) and, after a certain load, it presented displacement-caused tensile behavior due to element bending, which also led to displacing reinforcement. Both models evidenced that the first visible crack plateau was observed in the negative region of the curve.

Strain gage 14 behavior is only compression, since it is closer to the column/pile cap contact section, Figure 8 , and there is no bending interference. The experimental models presented sudden and exponential strain increase after the cracks emerged, whereas the numerical model presented linear and almost constant behavior, which proved the greater stiffness of the numerical model.

Strain gages 15 and 16 presented compressive behavior throughout the test. Measurements highlighted close results to that recorded for the numerical models. These points presented similar behavior between the experimental and numerical models, in comparison to other monitoring points. Such outcome can be explained by the lower incidence of cracks in the column region and, consequently, by the lower influence of material nonlinearity.
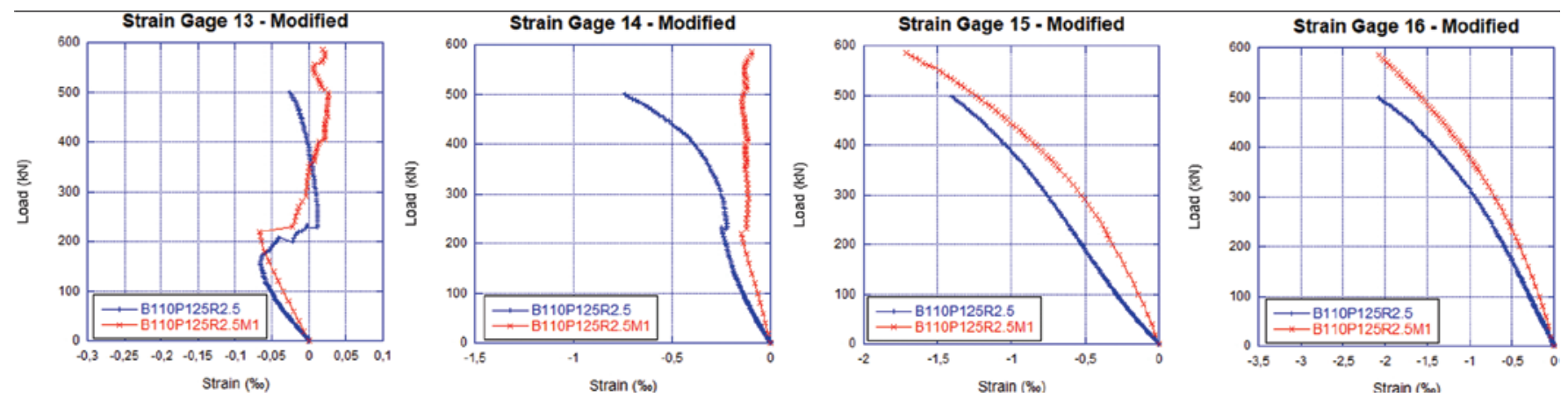

Figure 8

Load versus strain curves of column reinforcement, modified 


\section{Table 5}

Strains $(\varepsilon)$ and stresses $(\sigma)$ of B1 10P125R2.5 model, with modified values, and B1 10P125R2.5M1

\begin{tabular}{|c|c|c|c|c|c|c|c|c|}
\hline Strain gage & $0.33 . F_{u}$ & - & $0.66 . \mathrm{F}_{\mathrm{u}}$ & - & $\mathrm{F}_{\text {comp }}$ & - & $\mathrm{F}_{\mathrm{u}}$ & - \\
\hline- & $\varepsilon(\%)$ & $\sigma(\mathrm{MPa})$ & $\varepsilon(\% \circ)$ & $\sigma(\mathrm{MPa})$ & $\varepsilon(\%)$ & $\sigma(\mathrm{MPa})$ & $\varepsilon(\%)$ & $\sigma(\mathrm{MPa})$ \\
\hline \multicolumn{9}{|c|}{ B110P125R2.5 } \\
\hline 2 & 0.464 & 91.83 & 1.221 & 241.71 & 1.664 & 329.58 & 2.179 & 431.54 \\
\hline 13 & -0.049 & -9.69 & 0 & 0.1 & -0.023 & -4.47 & -0.027 & -5.32 \\
\hline 14 & -0.22 & -43.6 & -0.35 & -69.34 & -0.702 & -139.1 & -0.747 & -148.01 \\
\hline 15 & -0.502 & -99.46 & -0.978 & -193.74 & -1.375 & -272.28 & -1.412 & -279.6 \\
\hline 16 & -0.55 & -109.01 & -1.307 & -258.87 & -2.013 & -398.59 & -2 & -396.04 \\
\hline \multicolumn{9}{|c|}{ B110P125R2.5M1 } \\
\hline 2 & 0.203 & 40.2 & 1.211 & 239.8 & 1.724 & 341.39 & 2.35 & 465.35 \\
\hline 13 & -0.064 & -12.67 & 0.01 & 1.99 & 0.026 & 5.17 & 0.019 & 3.8 \\
\hline 14 & -0.136 & -26.89 & -0.127 & -25.15 & -0.144 & -28.5 & -0.093 & -18.46 \\
\hline 15 & -0.314 & -62.2 & -0.783 & -155.13 & -1.199 & -237.43 & -1.714 & -339.41 \\
\hline 16 & -0.404 & -80.08 & -1.024 & -202.77 & -1.521 & -301.19 & -2 & -396.04 \\
\hline
\end{tabular}

The two curves evidenced that the numerical model is less deformable than the experimental one and it proved the greater stiffness of the numerical model.

Results were analyzed in four load-steps: $33.0 \%, 66.0 \%$ and $100.0 \%$ failure load $\left(F_{u}\right)$, besides the load-step of the comparison load $\left(F_{\text {comp }}\right)$. Table 5 presents the strain $(\varepsilon)$ and stress $(\sigma)$ results of these load-steps. Figure 9 shows the stress values of column anchorage and tie reinforcements in the comparison load $\left(\mathrm{F}_{\text {comp }}\right)$. There were variations along the anchorage reinforcement. Stress was almost constant at the monitoring points above the column/pile cap contact section; it abruptly decreased in points below this section.

\subsection{Crack pattern and failure modes}

According to Munhoz [1], the first visible cracks appeared in the
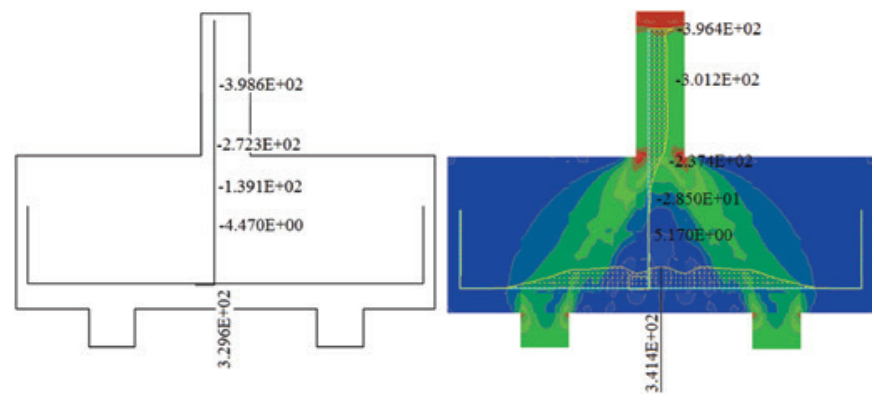

\section{Figure 9}

Stresses distribution of column anchorage

reinforcement and tie reinforcement, in comparison load, B1 10P125R2.5 and B1 10P125R2.5M1 models center of the inferior face of the pile cap. They spread through half of the pile cap height and recorded low opening values; therefore, these cracks were not critical. Subsequently, inclined cracks emerged and headed towards the compressive struts. This outcome proved the existence of stress flows in this direction - these cracks evolved to failure plane conformation. There were no significant cracks in the superior node, fact that proves the prevalence of compressive stress. The numerical model presented crack features similar to the ones described in the experimental model. Table 6 presents results of the first cracks, which are visible $\left(F_{r p p}\right)$, centered $\left(F_{r, c}\right)$ and inclined $\left(F_{r i}\right)$ in the B110P125R2.5 and B110P125R2.5M1 models. This table also depicts the relation between theses loads and the failure load $\left(F_{u}\right)$ in each model.

First visible cracks in experimental models were centered: $F_{r, p}=F_{r, c}$; however, the first inclined cracks heading towards the compressive struts were only observed later. First cracks emerging in the numerical models were not centered; however, they happened in the same load-step of the inclined cracks: $F_{r, p}=F_{r, i \neq} F_{r, c}$. Figure 10 shows ultimate patterns of the cracks in both models, they were similar and presented cracks either in the tie reinforcement region or towards the compressive struts.

Both models presented crack openings towards the compressive struts proved the existence of stress flows going in such direction. There was crack opening in the tie reinforcement region.

According to Munhoz [1], experimental models presented concrete failure in the superior, inferior, or in both node regions, after a failure plane emerged in the same direction of stress flows, with intense cracking. Numerical models presented similar failure modes, which reached compressive strength $\left(f_{c k}\right)$ after intense cracking in the nodal regions, as seen in Figure 11.

Model failures are influenced by the splitting effect of the concrete,

\section{Table 6}

Loads relative to crack opening of B1 10P125R2.5 and of B1 1OP125R2.5M1 models

\begin{tabular}{|c|c|c|c|c|c|c|c|}
\hline Model & $\begin{array}{c}\mathbf{F}_{\mathrm{u}} \\
(\mathbf{k N})\end{array}$ & $\begin{array}{c}\mathbf{F}_{\mathrm{r}, \mathrm{p}} \\
(\mathbf{k N})\end{array}$ & $\begin{array}{c}\mathbf{F}_{\mathrm{r}, \mathrm{p}} / \mathbf{F}_{\mathrm{u}} \\
(\%)\end{array}$ & $\begin{array}{c}\mathbf{F}_{\mathrm{r}, \mathrm{i}} \\
(\mathbf{k N})\end{array}$ & $\begin{array}{c}\mathbf{F}_{\mathrm{r}, \mathrm{i}} / \mathbf{F}_{\mathrm{u}} \\
(\%)\end{array}$ & $\begin{array}{c}\mathbf{F}_{\mathrm{r}, \mathrm{c}} \\
(\mathbf{k N})\end{array}$ & $\begin{array}{c}\mathbf{F}_{\mathrm{r}, \mathrm{c}} / \mathbf{F}_{\mathrm{u}} \\
(\%)\end{array}$ \\
\hline B110P125R2.5 & 577.08 & 198.00 & 34.31 & 220.00 & 38.12 & 198.00 & 34.31 \\
\hline B110P125R2.5M1 & 585.00 & 240.00 & 41.03 & 240.00 & 41.03 & 290.00 & 49.57 \\
\hline
\end{tabular}



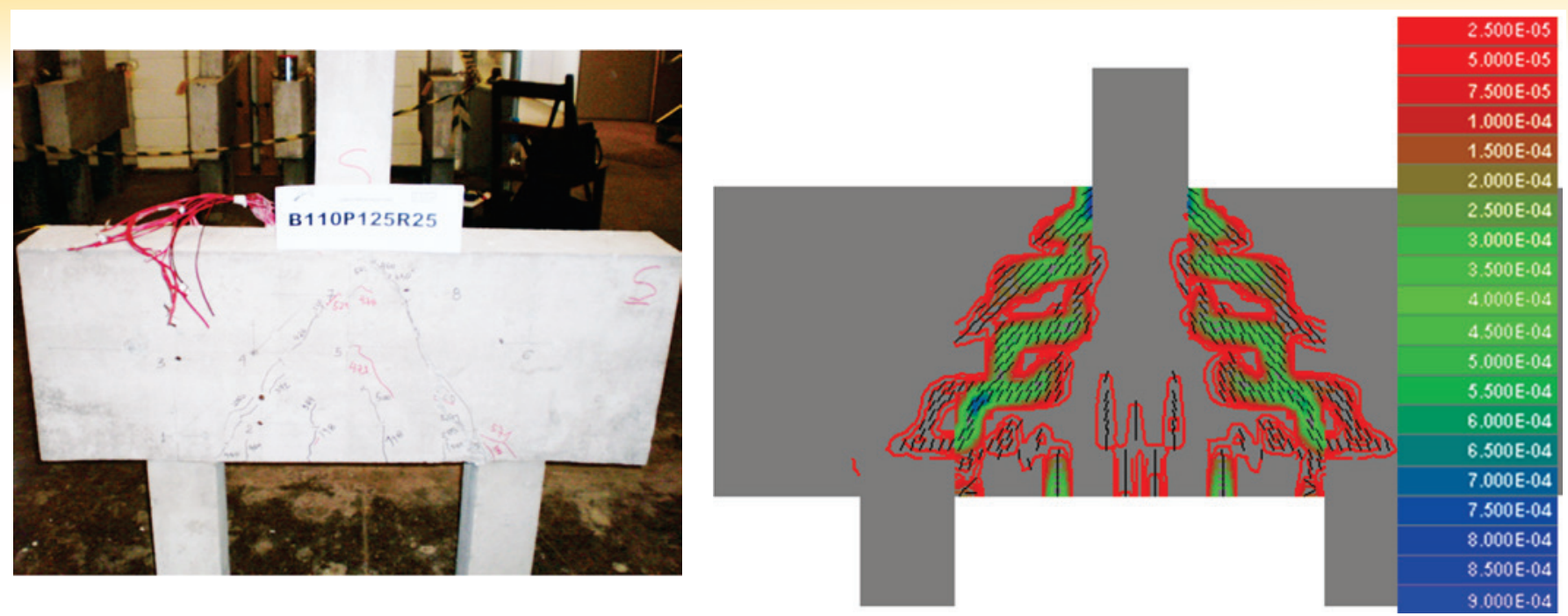

\section{Figure 10}

Ultimate crack pattern of B1 10P125R2.5 and of B1 10P125R2.5M1 models
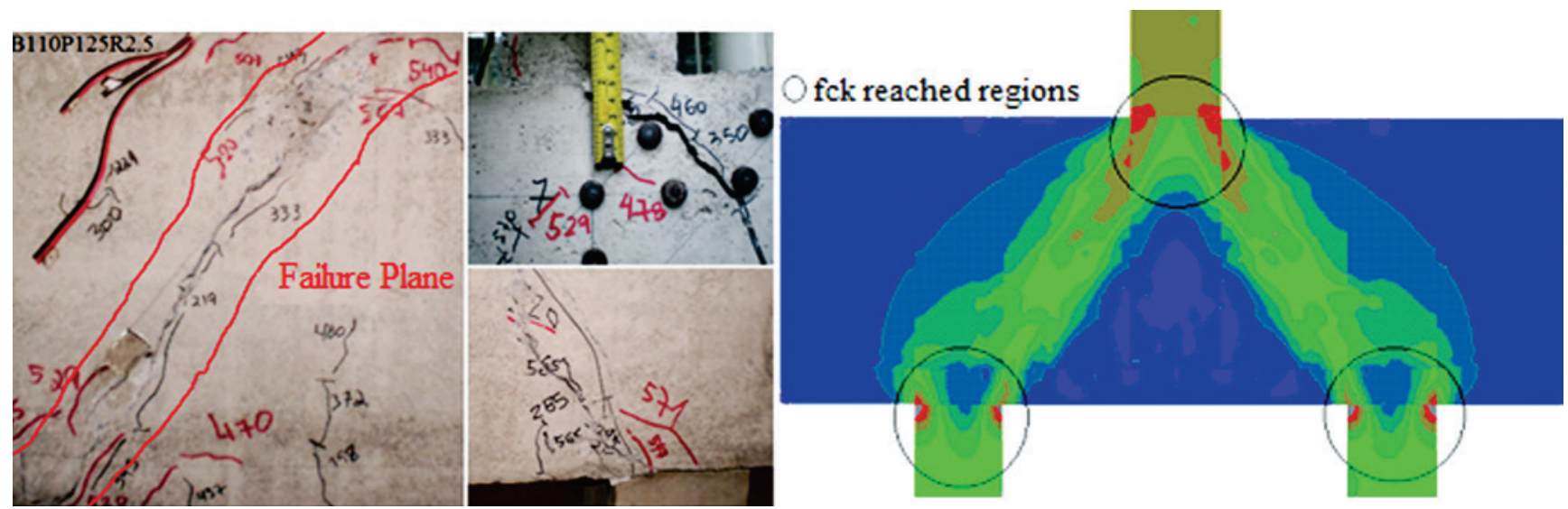

Figure 11

Failure models of B1 10P125R2.5 and of B1 10P125R2.5M1 models

which is explained by the emergence of cracks (caused by the tensile stress action perpendicular to the struts) parallel to the compressive stress flows.

\section{Parametric analysis of numerical models}

\subsection{Load versus displacement curves and failure modes}

Load versus displacement curves, shown in Figure 12, consist in the results of external load and in vertical displacement measurements in the inferior centered face of numerically-simulated pile caps. According to Figure 12, the load versus displacement curves of modified numerical (M2, M3, and M4) and experimental (M1) models presented similar behaviors. Small plateaus can be seen in a certain test point; they were caused by the emergence of the first significant crack opening, modify the curve inclination due to model stiffness changes.

Table 7 presents failure load values $\left(F_{u}\right)$, comparison load $\left(F_{\text {comp }}\right)$, maximum failure displacement $\left(\mathrm{W}_{\mathrm{Fu}}\right)$ and comparison displacement load $\left(\mathrm{W}_{\mathrm{Fcomp}}\right)$. This table also shows the $\mathrm{F}_{\mathrm{u}, \mathrm{Mi}} / \mathrm{F}_{\mathrm{u}, \mathrm{M} 1}$ relation between modified anchorage reinforcement length models M2, M3 and $\mathrm{M} 4$, and model $\mathrm{M} 1$. The $\mathrm{W}_{\mathrm{Fcomp}, \mathrm{Mi}} / \mathrm{W}_{\mathrm{Fcomp}, \mathrm{M} 1}$ relation is used to analyze displacements in comparison load; $\mathrm{M} 1$ and $\mathrm{M}_{\mathrm{i}}$ are the same indices described before.

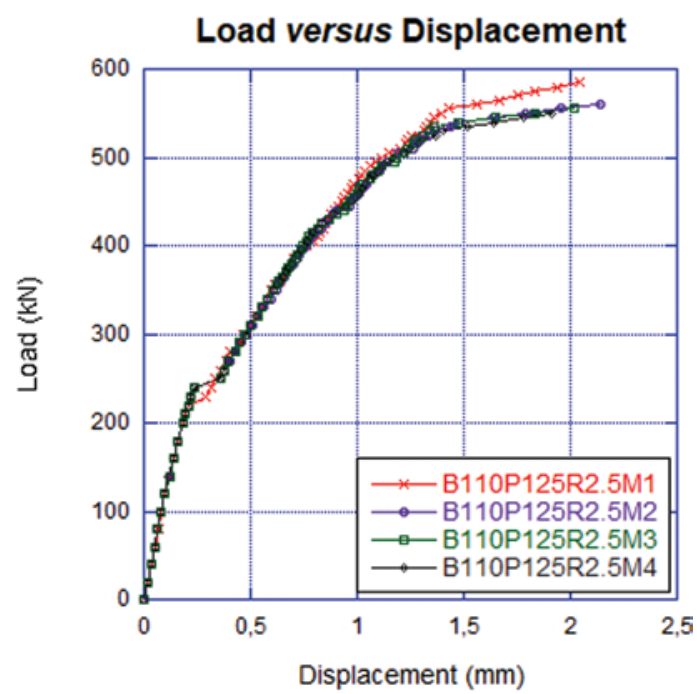

\section{Figure 12}

Load versus displacement curves of numerical models 


\section{Table 7}

Failure loads, comparison loads, comparison displacement loads and maximum failure displacements, of numerical models

\begin{tabular}{|c|c|c|c|c|c|c|}
\hline Model & $\begin{array}{c}F_{4} \\
(\mathrm{kN})\end{array}$ & $\begin{array}{l}F_{\text {comp }} \\
(\mathrm{kN})\end{array}$ & $\begin{array}{l}F_{u, M i}, F_{u, M l} \\
i=1,2,3,4\end{array}$ & $\begin{array}{l}W_{\text {Fcomp }} \\
(\mathrm{mm})\end{array}$ & $\begin{array}{c}\mathrm{W}_{\text {Fu,teor,Mi }}, \mathrm{W}_{\text {Fu,teor,M1 }} \\
\mathrm{i}=\mathbf{1}, \mathbf{2}, \mathbf{3}, \mathbf{4}\end{array}$ & $\begin{array}{l}W_{\mathrm{Fu}} \\
(\mathrm{mm})\end{array}$ \\
\hline \multicolumn{7}{|c|}{ B1 10P125R2.5 } \\
\hline $\mathrm{B} 110 \mathrm{P} 125 \mathrm{R} 2.5 \mathrm{M} 1$ & 585.00 & \multirow{4}{*}{491.83} & 1.00 & 1.060 & 1.00 & 2.044 \\
\hline $\mathrm{B} 110 \mathrm{P} 125 \mathrm{R} 2.5 \mathrm{M} 2$ & 560.00 & & 0.96 & 1.118 & 1.05 & 2.142 \\
\hline B1 10P125R2.5M3 & 555.00 & & 0.95 & 1.116 & 1.05 & 2.022 \\
\hline B1 10P125R2.5M4 & 550.00 & & 0.94 & 1.119 & 1.06 & 1.911 \\
\hline
\end{tabular}

Modified models (M2, M3 and M4) presented failure load results of modifying anchorage reinforcement length similar to the ones recorded for the experimental model $\mathrm{M} 1$. The $\mathrm{F}_{\mathrm{u}, \mathrm{Mi}} / \mathrm{F}_{\mathrm{u}, \mathrm{M} 1}$ relation showed $6.0 \%$ maximum difference between failure loads. Therefore, anchorage reinforcement length decrease is not an essential factor influencing pile cap failures.

These results were expected, since the behavior of the pile cap failure models is given by concrete crushing in the superior and/or inferior node regions, as observed by Blévot \& Frémy [2], Mautoni [3], Adebar, Kuchma \& Collins [12], Buttignol [4] and Delalibera [5]. According to these authors, pile caps reach concrete failure due to the emergence of cracks in the compressive struts stress flows (splitting effect).

Maximum displacements $\left(\mathrm{W}_{\mathrm{Fu}}\right)$ presented some result differences; however, curves in Figure 12 evidenced that the behaviors observed throughout the tests are similar.

Displacement loads $\left(\mathrm{W}_{\mathrm{Fcomp}}\right)$ were used in order to achieve a better comparison. The $\mathrm{W}_{\mathrm{Fcomp}, \mathrm{Mi}} / \mathrm{W}_{\mathrm{Fcomp}, \mathrm{M} 1}$ relation highlighted that modified model displacement (M2, M3 and M4) values did not present critical differences in comparison to values recorded for experimental models M1.

\subsection{Reinforcement strain-stress and stress flows}

The position of the monitoring point in the anchorage reinforcement is shown in Figure 1. Only part of the monitoring point results will be represented due to the symmetry and similar results shown by the models.

\section{Table 8}

Numerical models reinforcement strain-stress

\begin{tabular}{|c|c|c|c|c|c|c|c|c|}
\hline \multirow{2}{*}{ Strain gage } & \multicolumn{2}{|c|}{$0.33 . F_{u}$} & \multicolumn{2}{|c|}{$0.66 . F_{u}$} & \multicolumn{2}{|c|}{$\mathrm{F}_{\text {comp }}$} & \multicolumn{2}{|c|}{$\mathrm{F}_{\mathrm{u}}$} \\
\hline & $\varepsilon(\%)$ & $\sigma(\mathrm{MPa})$ & $\varepsilon(\% \circ)$ & $\sigma(\mathrm{MPa})$ & $\varepsilon(\% \circ)$ & $\sigma(\mathrm{MPa})$ & $\varepsilon(\% \circ)$ & $\sigma(\mathrm{MPa})$ \\
\hline \multicolumn{9}{|c|}{ B110P125R2.5M1 } \\
\hline 2 & 0.203 & 40.20 & 1.211 & 239.80 & 1.724 & 341.39 & 2.350 & 465.35 \\
\hline 13 & -0.064 & -12.67 & 0.010 & 1.99 & 0.026 & 5.17 & 0.019 & 3.80 \\
\hline 14 & -0.136 & -26.89 & -0.127 & -25.15 & -0.144 & -28.50 & -0.093 & -18.46 \\
\hline 15 & -0.314 & -62.20 & -0.783 & -155.13 & -1.199 & -237.43 & -1.714 & -339.41 \\
\hline 16 & -0.404 & -80.08 & -1.024 & -202.77 & -1.521 & -301.19 & -2.000 & -396.04 \\
\hline \multicolumn{9}{|c|}{ B110P125R2.5M2 } \\
\hline 2 & 0.133 & 26.34 & 1.058 & 209.51 & 1.638 & 324.36 & 2.097 & 415.25 \\
\hline 13 & -0.061 & -12.00 & -0.019 & -3.83 & -0.004 & -0.70 & 0.004 & 0.73 \\
\hline 14 & -0.121 & -24.02 & -0.107 & -21.27 & -0.086 & -17.10 & -0.057 & -11.24 \\
\hline 15 & -0.276 & -54.55 & -0.737 & -145.88 & -1.207 & -239.01 & -1.641 & -324.95 \\
\hline 16 & -0.354 & -70.06 & -0.962 & -190.55 & -1.521 & -301.19 & -1.930 & -382.18 \\
\hline \multicolumn{9}{|c|}{ B110P125R2.5M3 } \\
\hline 2 & 0.131 & 25.94 & 1.043 & 206.53 & 1.637 & 324.16 & 2.064 & 408.71 \\
\hline 13 & - & - & - & - & - & - & - & - \\
\hline 14 & -0.119 & -23.56 & -0.121 & -24.04 & -0.101 & -19.90 & -0.111 & -21.90 \\
\hline 15 & -0.275 & -54.48 & -0.719 & -142.46 & -1.206 & -238.81 & -1.629 & -322.57 \\
\hline 16 & -0.354 & -70.06 & -0.942 & -186.57 & -1.521 & -301.19 & -1.907 & -377.62 \\
\hline \multicolumn{9}{|c|}{ B110P125R2.5M4 } \\
\hline 2 & 0.130 & 25.74 & 1.042 & 206.34 & 1.648 & 326.34 & 2.046 & 405.15 \\
\hline 13 & - & - & - & - & - & - & - & - \\
\hline 14 & - & - & - & - & - & - & - & - \\
\hline 15 & -0.272 & -53.80 & -0.697 & -138.10 & -1.194 & -236.44 & -1.547 & -306.34 \\
\hline 16 & -0.354 & -70.06 & -0.922 & -182.65 & -1.521 & -301.19 & -1.873 & -370.89 \\
\hline
\end{tabular}



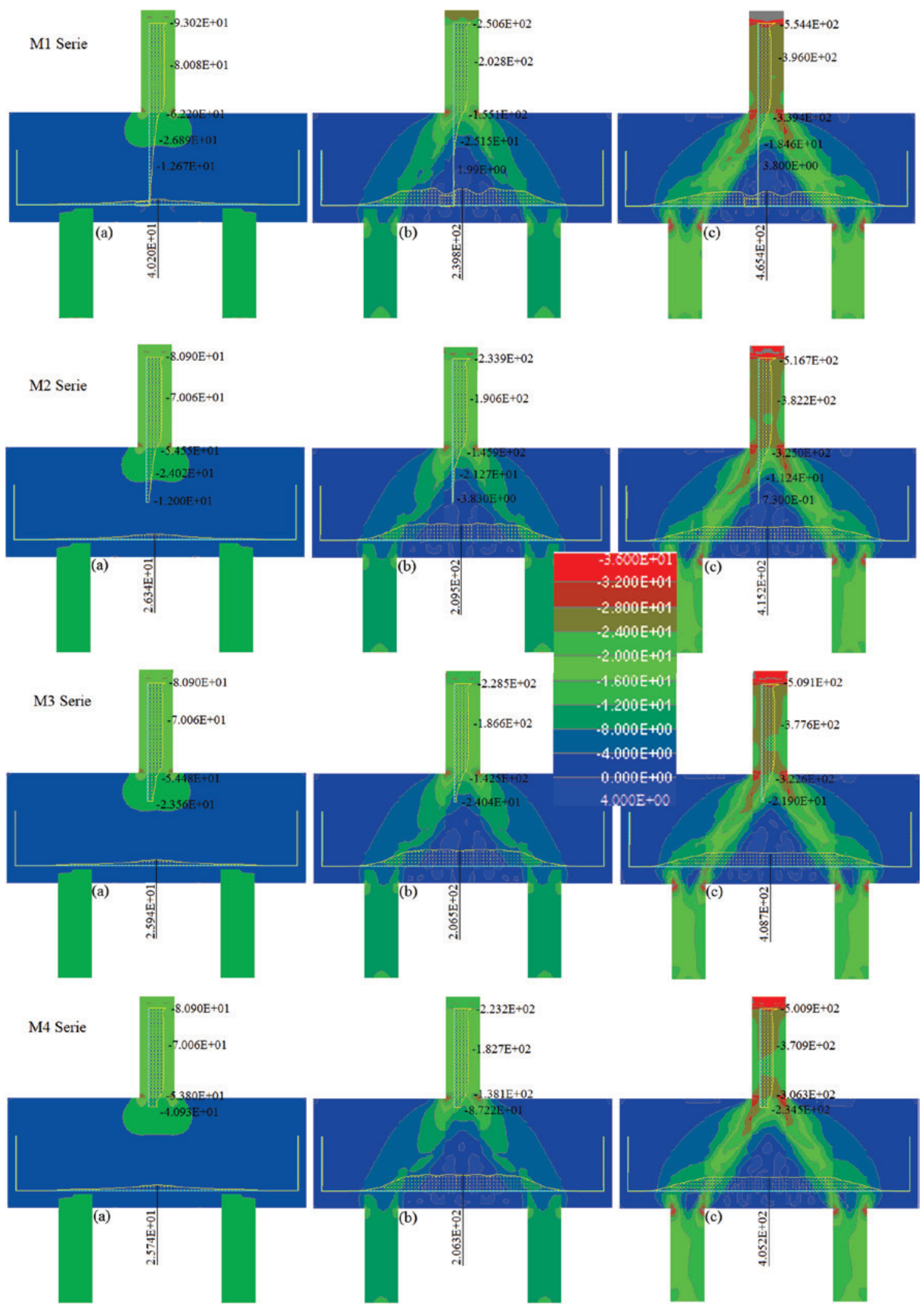

Figure 13

Reinforcement stresses and stress flows (in MPa), cases (a) - 0,33Fu, (b) - 0,66Fu and (c) - Fu, of numerical models 
Table 8 presents the strain $(\varepsilon)$ and stress $(\sigma)$ results; stress was calculated based on the Hooke's Law. Loads related to failure load $\left(F_{u}\right) 66 \% . F_{u}, 33 \% . F_{u}$ and to load comparison $\left(F_{\text {comp }}\right)$ in each strain gage are also shown in this table.

In order to facilitate the visualization of results, values in Table 8 were allocated to their respective positions along the reinforcement (Figure 13). Cases (a), (b) and (c) regard reinforcement stress and stress flow in $0.33 \mathrm{~F}_{u}, 0.66 \mathrm{~F}_{u}$ and $\mathrm{F}_{u}$, respectively.

Based on results of the presented models, it is observed the decreasing of strain and stress along the column reinforcement anchorage length.

Figure 13 depicted the abrupt stress decrease along the anchorage reinforcement length, mainly in the column/pile cap contact section, as discussed by Fusco [11]. From the different loads, (a), (b) and (c), highlighted that such phenomenon was observed in the numerical model simulating the experimental model (M1) and in models presenting modified reinforcement (M2, M3 and M4). Therefore, reinforcement anchorage length can be decreased since stress dissipates faster than the expected.

Stress flows followed the same behavior in models M1, M2, M3 and M4. Compressive struts evolution is proportional to the evolution of the applied load; there is gradual stress flows and compressive struts propagation inside the pile caps. The compressive struts formation in case (a) is observed in the superior node of the pile caps and it spread towards the inferior node regions, as seen in cases (b) and (c). Because stress moves towards the structure for more rigid points, stress located in the superior node region goes towards the inferior nodes, because the stiffness at this point is greater than in the center of the pile cap where it iss possible observing larger displacements. Stress flows evidenced that compressive struts got a characteristic inclination.

Moreover, it is observed that there is non-uniformity in pile stress, the internal regions (near column) of the piles are more solicited, and it corroborated the results by Buttignol [4] and Delalibera [5]. Overall, designing models do not take into consideration the nonuniform distribution of stress; they are often based on equilibrium at the center of the piles. Equilibrium cannot be taken into consideration for the centered section of the superior node in the column, i.e., stress concentration is greater in the decentered section of the column, i.e., as suggested in the refined model by Adebar, Kuchma

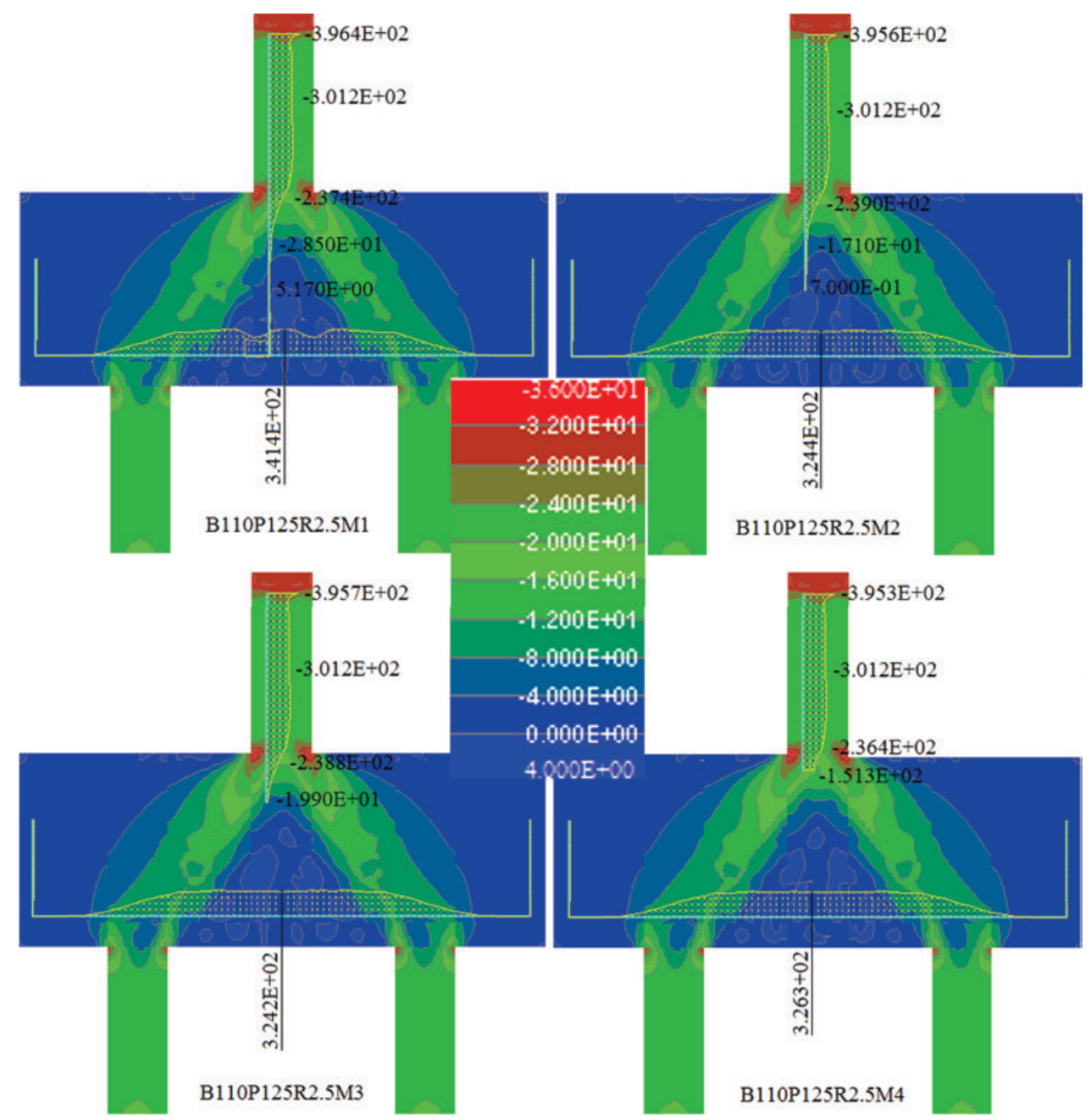

Figure 14

Reinforcement stresses and stress flows (in $\mathrm{MPa}$ ) of numerical models, for $\mathrm{F}_{\text {comp }}$ 
Table 9

Loads related to crack opening of numerical models

\begin{tabular}{|c|c|c|c|c|c|c|c|}
\hline Modelo & $\begin{array}{c}\mathbf{F}_{\mathrm{u}} \\
(\mathbf{k N})\end{array}$ & $\begin{array}{c}\mathbf{F}_{\mathrm{r}, \mathrm{p}} \\
(\mathrm{kN})\end{array}$ & $\begin{array}{c}\mathbf{F}_{\mathrm{r}, \mathrm{p}} / \mathbf{F}_{\mathrm{u}} \\
(\%)\end{array}$ & $\begin{array}{c}\mathbf{F}_{\mathrm{r}, \mathrm{i}} \\
(\mathbf{k N})\end{array}$ & $\begin{array}{c}\mathbf{F}_{\mathrm{r}, \mathrm{i}} / \mathbf{F}_{\mathrm{u}} \\
(\%)\end{array}$ & $\begin{array}{c}\mathbf{F}_{\mathrm{r}, \mathrm{r}} \\
(\mathbf{k N})\end{array}$ & $\begin{array}{c}\mathbf{F}_{\mathrm{r}, \mathrm{c}} / \mathbf{F}_{\mathrm{u}} \\
(\%)\end{array}$ \\
\hline \multicolumn{7}{|c|}{$\mathbf{B 1 1 0 P 1 2 5 R 2 . 5}$} \\
\hline B110P125R2.5M1 & 585.00 & 240.00 & 41.03 & 240.00 & 41.03 & 290.00 & 49.57 \\
\hline B110P125R2.5M2 & 560.00 & 250.00 & 44.64 & 250.00 & 44.64 & - & - \\
\hline B110P125R2.5M3 & 555.00 & 250.00 & 45.05 & 250.00 & 45.05 & - & - \\
\hline B110P125R2.5M4 & 550.00 & 250.00 & 45.45 & 250.00 & 45.45 & - & - \\
\hline
\end{tabular}

\& Collins [12]. Compressive struts also had positive influence on the behavior of the reinforcement arranged on the top of the piles, because observes an abrupt strain and stress decrease in the inferior node region.

For a better comparison, Figure 14, presents the comparison load $\left(F_{\text {comp }}\right)$ results of pile caps at $491.83 \mathrm{kN}$, for different reinforcement anchorage length in models M1, M2, M3 and M4.

Based on Figure 14, the same load $\left(\mathrm{F}_{\text {comp }}\right)$ applied to models presenting different anchorage reinforcement length presented similar reinforcement stress and stress flows behavior, thus changes in reinforcement did not significantly influence the models.

In general, the monitoring points in column regions presented strain and stress practically constant; and the decrease occurs in the inferior points of the column/pile cap contact section. This phenomenon is caused by the positive influence of compressive struts on the superior node region of the pile cap. Compressive stress in these regions collaborates for a confining action of concrete on steel and such process increases material contact, improving adhesion between materials and fastens reinforcement dissipation in narrower sections of the anchorage reinforcement. Stress is almost null in regions near the inferior monitoring points located approximately $20,0 \mathrm{~cm}$ below the pile cap face.

From these observations it is concluded that anchorage necessary for force transference between columns and pile caps is a lower value than the designed and detailed values often used in structural designs of reinforced concrete. Reinforcement stress dissipated throughout load application, as discussed by Fusco [11]. However, the pile caps designing models did not take these phenomena into consideration.

\subsection{Crack pattern and failure modes}

Table 9 presents the load results of the first visible $\left(F_{r, p}\right)$, centered $\left(F_{r, c}\right)$ and inclined $\left(F_{r, i}\right)$ cracks in the inferior face region of the pile caps. This table also shows the relation between these loads and failure load $\left(F_{u}\right)$.

Results of the comparison set the $F_{r, p} / F_{u}$ and $F_{r, i} / F_{u}$ relations throughout the anchorage reinforcement length in the modified models (M1, M2, M3 and M4), which did not present variations higher than $5.0 \%$. Therefore, anchorage reinforcement length variation is not a preponderant factor influencing the emergence of cracks in pile caps, since the models presented similar behaviors.

Comparisons between results became unfeasible to failure load $\left(F_{u}\right)$ because the numerical models failed in different load-steps. Thus, the load comparison $\left(\mathrm{F}_{\text {comp }}\right) 491,83 \mathrm{k} N$ will be used. The magnitude of the cracks is expressed through color scales; open- ing measurements are recorded in meters, as shown in Figure 15. Based on the figures, cracks are concentrated in three different regions: first, in the inferior region of the pile caps - from the inferior face of the pile upwards. However, these cracks had low opening magnitude (as seen in the color scale) and did not reach half of the pile cap height, due to bending. The second region is located in the inferior portion of the pile cap; however, it did not begin or reached the lowest region of the pile caps, besides having low opening magnitude - in some cases, these cracks joined the ones caused by bending. The third region concerned the inclined cracks going towards the compressive struts and the ones presenting greater opening magnitude, which led to failure plane formations from the inferior node region near the piles to the superior node region near the column.

Crack patterns in models M1, M2, M3 and M4 presented few differences for column reinforcement anchorage length modifications. These patterns mainly changed the magnitude of the cracks. Such assumption can be verified through the pile caps presenting smaller anchorage length, because they overall presented larger crack openings. Decreases in the length of these reinforcements made pile caps more susceptible to crack opening; however, such results did not present behavioral disparities.

The failure mode of all models presented concrete failure at the superior and/or inferior nodes. Failure planes emerged towards the compressive struts after intense cracking in inclined directions; later on, concrete compressive strength $\left(f_{c k}\right)$ was reached. The failure mode of the models was influenced by splitting effect, i.e., by the emergence of cracks (caused by tensile stresses action perpendicular to struts) parallel to the compressive stress flow. The failure modes of the presented models complied with item 4.3 in the discussion part.

\section{Conclusions}

The main aim of this study was to assess the influence of column reinforcement anchorage length on pile caps with two piles. Numerical pile caps were simulated in experimental reference models by using a software based on the Finite Elements Method, which takes into account the non-linearity of the materials. The behavior of the pile caps was parametrically analyzed under different column anchorage lengths: $34.0 \mathrm{~cm}, 20.0 \mathrm{~cm}, 10.0 \mathrm{~cm}$ and $3.0 \mathrm{~cm}$. The analyzed results concerned the load versus displacement curves, failures loads, reinforcement strain and stress, stress flows, crack patterns and failure modes.

Numerical results complied with the results recorded for experimental reference models, which were qualitatively positive. Some 


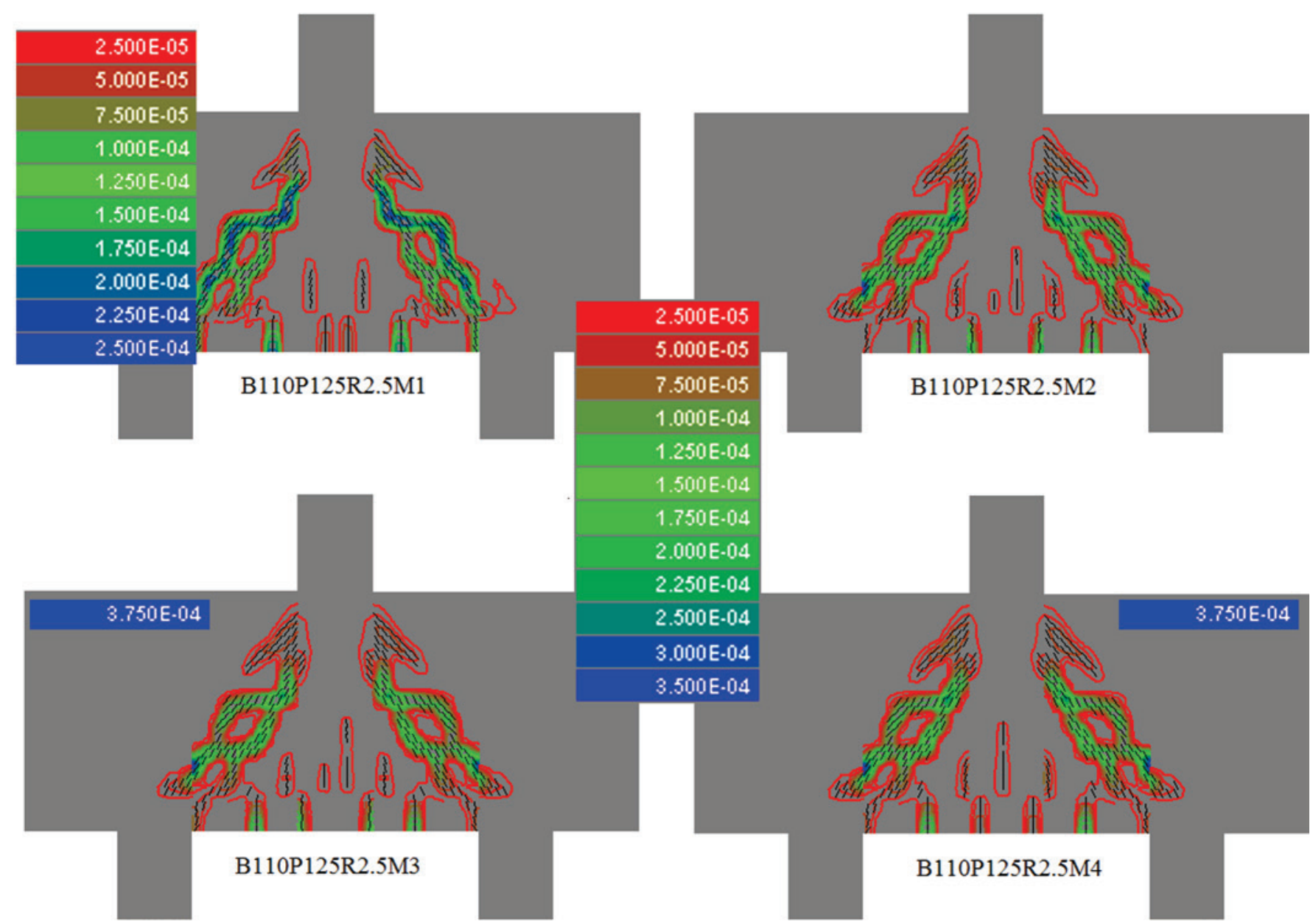

Figure 15

Crack patterns of numerical models, for comparison load $\left(F_{\text {comp }}\right)$

results presented disparities mainly due to stiffness difference between models. Numerical models are more rigid than the experimental ones, and these results corroborate those recorded by Buttignol [4] and Delalibera [5].

Besides the three reasons cited by Delalibera [5] to explain greater stiffness in numerical models, the parameters used in interface elements, which simulated the contact between concrete and steel plates, influenced the final stiffness of the element.

The numerical analyses showed that simulated pile caps presented similar internal mechanism function behavior in these elements. Stress flows, failure modes and crack patterns recorded similar results.

Pile caps presented few behavior modifications in the parametric numerical analysis after anchorage reinforcement length modifications. Failure loads $\left(F_{u}\right)$ did not change due to these modifications; such results were expected, since the pile cap failure model caused by concrete crushing happened in the nodal regions after crack emergences, which met the struts stress flows, also known as splitting effect.

There was abrupt decrease in column anchorage reinforcement strain and stress results, mainly in the column/pile cap contact section region, where the compressive struts formed in. The phenomenon was observed in all analyzed models, in both numerically simulated experimental models, based on Munhoz [1]. The fast stress dissipation is explained by the positive influence of the compressive stress formed in the superior node region of the pile caps, i.e, the confining action of the compressive struts collaborates to stress transference between reinforcement and concrete.

The parametric numerical analysis showed that, in these cases, the anchorage reinforcement length modifications did not have significant influence on the behavior of the models, i.e., length was not a preponderant factor influencing the mechanism functions of two-pile caps.

\section{Acknowledgement}

To CAPES Agency for the support that made this publication possible, to Civil Engineering, Architecture and Urbanism School of UNICAMP, as wells as to Structure Department and to the professors for the given support and for the availability of tools and software that made this research viable. 


\section{References}

[1] MUNHOZ, F. S. Experimental and numerical analysis of rigid two-pile caps with square and rectangular column and different rates of column reinforcement. Thesis (Doctored). São Carlos School of Engineering, University of São Paulo. São Carlos, Brazil, 2014. (in Portuguese).

[2] BLÉVOT, J. L.; FRÉMY, R. Semelles sur pleux. Institut Technique du Bátiment et des Travaux Publics. Paris, Françe, 1967. (in French).

[3] MAUTONI, M. Bloco sobre dois apoios. Grêmio Politécnico. São Paulo, Brasil, 1972.

[4] BUTTIGNOL, T.E.T. Computational Analysis of Pile Caps. Master Dissertation. School of Civil Engineering, Architecture and Urbanism, University of Campinas. Campinas, Brazil, 2011. (in Portuguese).

[5] DELALIBERA, R. G. Numerical and experimental analysis of two pile caps submitted to the action of a load centered and eccentric. Thesis (Doctored). São Carlos School of Engineering, University of São Paulo. São Carlos, Brazil, 2006. (in Portuguese).

[6] MIGUEL, G. M. Numerical and experimental analysis of three-pile caps. Thesis (Doctored). São Carlos School of Engineering, University of São Paulo. São Carlos, Brazil, 2000. (in Portuguese).

[7] ACI COMMITTEE 318 ON STANDARD BUILDING CODE. Building code requirements for structural concrete - $\mathrm{ACl}$ 318R-14, American Concrete Institute, 2014.

[8] COMITÉ EURO-INTERNATIONAL DU BÉTON. CEB/FIP MODEL CODE MC-2010 - Design code. International Federation for Structural Concrete, 2010.

[9] BRAZILIAN ASSOCIATION STANDARS. NBR 6118:2014 Design of concrete structures. Rio de Janeiro, Brazil, 2014. (in Portuguese).

[10] CERVENKA, V; JENDELE, L. e CERVENKA, J. ATENA Program Documentation - Part 1: Theory. Prague, Czech Republic, 2015.

[11] FUSCO, P.B. Técnicas de armar as estruturas de concreto. Editora PINI Ltda. São Paulo, Brasil, 1994.

[12] ADEBAR, P.; KUCHMA, D.; COLLINS, M. P.. Strut-and-tie models for design of pile caps: an experimental study. $\mathrm{ACl}$ Journal, v. 87, Jan/Feb-1990; p. 81-91. 